\title{
ГЕОДЕЗІЯ
}

GEODESY

\section{UDC 548.28;622.21}

\section{P. BARAN \\ Ivano-Frankivsk national technical university of oil and gas, 15, Karpatskaya str., Ivano-Frankivsk, Ukraine, 76019. \\ EFFECTIVE METHODS OF APPROXIMATION AND PROGNOSTICATION OF SETTLING ENGINEERING BUILDINGS}

\author{
https://doi.org/10.23939/istcgcap2018.01.005
}

Aim. Improvements of the methods of approximation of settling by exponential, finely-rational, polynomial, and sinusoidal functions with the definition of intervals between observation cycles. Methods and results of the work. The methods of approximation and prognostication of settling of control benchmarks of building are examined. Special attention is given to the exponential function with the use of simple and exact method of determination of coefficient of intensity of settling using the mean values of the settling and time intervals, which allows substantially a decrease in the volume of iteration calculations. The exact (integral) method of determination coefficient of intensity of settling offered in the article allows to practically withdraw the iteration process of calculation and to specify aspect or soil porosity ratios, which are determined from laboratory soil researches using data of approximation of settling. For replacement of methods of polynomial and sinusoid the algorithm of approximation of settling is worked out by the method of finely-rational function, proposed by Ziborov [Ziborov, 1972], and methods of determination of inter cyclical intervals for the execution of rational monitoring observations on vertical displacements of buildings. Efficiency of application of method of finely-rational function and practical pointlessness of the use of the polynomial and sinusoid for approximation of settling function is shown. Scientific novelty. The executed improvements promote efficiency and repressiveness of the approximation data, and assist diminishing calculations volume. Practical value. Consists in development of the method for calculation of time intervals between observation cycles for the different functions of approximation, which practically allows excluding the iteration process of determination of the coefficient of intensity of settling for exponent and using of this coefficient for clarification of coefficients of compressibility or soil porosity, which are determined using its laboratory researches. It is proven, that the method of finely-rational function (FRF) proposed in [Ziborov, 2004], is simplest in the organization of calculations.

Key words: monitoring, settling, approximation, exponent, finely-rational function, polynomial, sinusoid, intercycles interval of observations.

\section{Introduction}

Monitoring of engineering building, especially height, unique and ecologically dangerous, requires the use of effective and exact methods of approximation of settlings of control marks and benchmarks. In practice for approximation and prognostication of settling there are common methods of exponential, polynomial, and sinusoidal functions. First is the most effective for the layer of soil which has slow settling and has wide application with the use of physical and technical properties of soil, obtained during engineering geological researches.

Analysis of the last researches. By virtue of that approximation of settling is conducted by approximate calculation parameters of exponent [Viduev, Staroverov 1972; Ziborov, 1972] and partly [[Baran, 2012], then convergence of iterative process depend on that, how accurate the initial values of parameters of approximation will be selected. Therefore, with the purpose of improving the method of approximation by exponential function, the question of revision of methods of determination of coefficient of intensity of settling and its use appeared for clarification of physical and mechanical descriptions of soil (to compressibility or porosity) by the data of approximation of settling, i.e. integral indexes of the real subsidence process. Exactly approximation of settling by an exponential function differs substantially from a polynomial and sinusoid, which under condition of complication of calculative process allow only to approximate settlings which reduces their efficiency.

\section{Aim}

Improvements of the methods of approximation of settling by exponential, finely-rational, polynomial, and sinusoidal functions with the determination of intervals between observation cycles. 


\section{Methods and results of work}

\section{Determination of parameters of hypothetical model, accuracy and frequency of measuring of settlings.}

According to current national standards DSTUB V. 2.1-30: 2014 [DSTU B $\quad$ V.2.1-30:2014 Grunty...] the permissible mean square error of the measurement of settling must not exceed 1,2,5 and $10 \mathrm{~mm}$ accordingly for buildings erected on rocky, compact, bulk, and peat soils, and also for earthwork structures. Therefore, any geodetic work, and particularly monitoring observations begin with the calculation of necessary accuracy of the measurements. Complication of calculations is that before beginning observations it is necessary to choose correctly a so-called hypothetical (predictable) mathematical model, which can be used for description of the process of settling of the building.

In practice there is the most widespread model which is described by an exponential function

$$
S_{t}=S_{k}\left(1-e^{-k t}\right),
$$

where $S_{t}-$ is the forecast settling for time $t ; S_{k}-$ is the calculated final settling of building; $k-$ is a coefficient of intensity of settling.

For the calculation of the possible settling of building object by the size of house and its height we should determine mass of building $M$ and its the reduced pressure $P$ on soil, that will allow to calculate two parameters of settling process according to the course of mechanics of soils by the formulas:

$$
S_{k} \approx \frac{h m_{0} P}{1+\varepsilon} ; \quad P=\frac{V \gamma_{\mathrm{M}}}{F} ; \quad k \approx \frac{10^{5} \sqrt{m_{0}}}{t h},
$$

where $S_{k}, h$ - eventual settling of building and power settling layer of soil (depth of sole foundation); $m_{0}$ - coefficient of compressibility soil, which changes within limits $0,05-0,50) \cdot 10^{-6} \mathrm{~m}^{2} / \mathrm{n}$ $(1 \mathrm{n}=9.8 \mathrm{~kg})$ respectively for sand and clays; $\varepsilon$-coefficient of porosity of soil (dimensionless value) which is 0,$55 ; 0,60 ; 0,80$ accordingly for dense, medium-density and soft soils; $t$ - time period, month or year; $P$ - pressure on soil (building mass) at the level of sole foundation, $\mathrm{n} / \mathrm{m}^{2} ; \quad V$ - volume of building constructions (foundations, plates of ceiling, walls, partitions, roof and other), $\mathrm{m}^{3} ; \gamma_{\mathrm{M}}$ - density (volume mass) of concrete or steel, which is respectively 1600 and
$7800 \mathrm{~kg} / \mathrm{m}^{3}$ (or 16000 and $78000 \mathrm{n} / \mathrm{m}^{3}$ ); $F$ - is an area of soil under building, $\mathrm{m}^{2}$.

If a building or separate section of the size $18 \times 14 \mathrm{~m}$ occupies the area $252 \mathrm{~m}^{2}$ and the volume of reinforced concrete constructions is $400 \mathrm{~m}^{3}$, then $h=20 \mathrm{~m} ; m_{0}=0.05 \cdot 10^{-6}$ and $\varepsilon=0.60$ the pressure on soil is $P \approx \frac{400 \cdot 16000}{252} \approx 0.024 \cdot 10^{6} \mathrm{n} / \mathrm{m}^{2}$. Then the eventual settling of building and coefficient of intensity settling for period of $\mathrm{t}=12$ months will be:

$$
\begin{aligned}
S_{k} & \approx \frac{20 \cdot 0.05 \cdot 10^{-6} \cdot 0.024}{(1+0.60) 252} \approx 0.016 \mathrm{~m} \\
k & \approx \frac{10^{5} \cdot 10^{-3} \sqrt{0.05}}{12 \cdot 20} \approx 0.093 / \mathrm{mon}
\end{aligned}
$$

As shown below, and in Table 1, using these magnitudes it is possible to calculate, that stabilizing of such settling can become not less than in 60 months, when $S_{k} \approx 0.016\left(1-e^{-0,093 \cdot 60}\right) \approx 0.016 \mathrm{~m}$. By the determined parameter we can calculate the eventual settling $S_{k}$, the current values of settling $S_{t}$ in the interval $\Delta t=t_{k}-t_{0}$ from the beginning of observations till stabilizing of settling process.

For organization of leveling of control benchmarks, built-in the base of the erected building, it is necessary to set control intervals $\Delta t$ and $\Delta s$, which are used for determination of the speed of settling of building which substantially depend on composition of soil (the smallest dependence is on rocky and clay soils and bigger on sandy and especially on loess (porous) soils).

Speed of settling is determined by increments $\Delta s$ and $\Delta t$ and according to the formula

$$
v=\frac{\Delta s}{\Delta t},
$$

from where it is easi to define the relative error of speed of settling

$$
\frac{m_{v}}{v}=\sqrt{\left(\frac{m_{\Delta s}}{\Delta s}\right)^{2}+\left(\frac{m_{\Delta t}}{\Delta t}\right)^{2}} .
$$

Using the principle of identical influence of errors of two constituents of process of measurements, we can write down expressions for the permissible errors of measuring differences of settling and time interval:

$$
m_{\Delta s} \leq \frac{m_{v} \Delta s}{v \sqrt{2}} ; \quad m_{\Delta t} \leq \frac{m_{v} \Delta t}{v \sqrt{2}},
$$


where $\frac{m_{v}}{v}-$ relative error of determination of settling speed, which mainly is $1 / 10$, or $10 \%$ from the value of settling speed.

As in an initial period of building exploitation their settlings grow actively, and after the compression of soil they diminish gradually, then the time interval between the cycles of observations is expedient to elect with different difference $\Delta t$, taking for calculation the permanent variable of settling between cycles

$$
\Delta s=S_{k} / n,
$$

where $n-$ is accepted amount of working cycles of observations, for example, at four annual cycles during 3 years the magnitude $n=12$, when at $S_{k}=84 \mathrm{~mm}$, the inter cyclic settling is similar $\Delta s=7 \mathrm{~mm}$.

Then by the method of interpolation we can calculate values of the possible settling

$$
S_{t_{i}}=S_{t_{0}}+i \cdot \Delta s,
$$

where $S_{t_{0}}=0-$ settling of control benchmark in the 0 -th (initial) cycle of observations, as its height mark $H_{0}$ is considered as initial for determination of benchmark settling by the known dependence $\Delta S_{i}=H_{i}-H_{0}$ in all next cycles $i=1,2,3 \ldots, n$, but there are no needs for this because the time interval from the beginning of observations to any working cycle is possible to define from formula (1) by the following dependence

$$
t_{i}=-\frac{\ln \left(1-r_{i}\right)}{k}=-\frac{\ln (1-i / n)}{k} ; \quad r=\frac{S_{t}}{S_{k}}=\frac{i}{n} .
$$

\section{Table 1}

A calculation of rational inter cyclic time intervals of the settling measurements $\left(S_{k}=76 \mathrm{~mm} ; t_{k}=48\right.$ month $\left.n=8 ; \Delta S_{1}=9,5 \mathrm{~mm} ; k=0,058\right)$

\begin{tabular}{|c|c|c|c|c|c|c|c|c|c|}
\hline № of cycle & 0 & 1 & 2 & 3 & 4 & 5 & 6 & 7 & 8 \\
\hline$\Delta S, \mathrm{~mm}$ & 9.5 & 9.5 & 9.5 & 9.5 & 9.5 & 9.5 & 9.5 & 0.2 & - \\
\hline$S_{t,}, \mathrm{~mm}$ & 0 & 9.5 & 19.0 & 28.5 & 38.0 & 47.5 & 57.0 & 66.5 & 76.0 \\
\hline$t_{i}$, month. & 0 & 2.3 & 5.0 & 8.1 & 12.0 & 16.9 & 23.9 & 35.8 & 48 \\
\hline$\Delta t_{i, i+1}$, month & - & 2.3 & 2.7 & 3.1 & 3.8 & 5.0 & 7.0 & 12.0 & - \\
\hline$m_{\Delta t_{i, i+1}}$,day & - & 10 & 11 & 13 & 16 & 21 & 30 & 51 & 52 \\
\hline
\end{tabular}

In the stage of stabilizing of settling as result of approaching of nearby values of settlings to the $S_{k}$, the function of the logarithm in formula (7) degenerates, that is why it is necessary to take the value in numerator $\ln [(1-1 / n) / 2]$, which in this case is $\ln (0.0 .625) \quad=\quad-2,77$ and $t_{8} \approx-2.772 /-0.058 \approx 47.8$ month.

For visibility of planning of inter cyclic time intervals it is expedient to design the chart of settling, putting aside a value $t_{i}$ with an interval of 1 month for each $5 \mathrm{~mm}$ on horizontal axis of abscissas, and $S_{t_{i}}-$ on vertical axis of ordinates downward (settlings have a minus values) in the scale of $1: 1,1: 2,1: 5$, or $1: 10$ depending on exactness of leveling. The first two scales mainly are applied at the leveling of I-II classes and other at the III-IV classes. After that on the chart we can display the areas of placement $\Delta S_{1}$ and control graphically rational time intervals between the cycles of observations. For controlling time intervals between two nearby cycles it is possible to use the formula

$$
\Delta t_{i, i+1}=t_{i+1}-t_{i}=-\frac{1}{k} \ln \frac{S_{k}-S_{t_{i+1}}}{S_{k}-S_{t_{i}}} .
$$

So, for example, $S_{t_{1}}=9.5 \mathrm{~mm}, S_{t_{i_{2}}}=19 \mathrm{~mm}$ and $k=0.058$ month, then $\Delta t_{12}=2.66$ month, that corresponds the table 1 . Then according to formula (5) the permissible error of observance of the interval between cycles of the geodetic measurements must not exceed $m_{\Delta t}= \pm 2,66 / 7.1= \pm 0.37$ month $= \pm 11$ days.

\section{Methods of settling approximation}

\section{Approximation of settling by the exponent.}

Settling of control benchmark is calculated as a difference of two height marks, obtained in contiguous cycles by the formula

$$
S_{t_{i}}=H_{i}-H_{i-1} \text {, }
$$


Which are obtained from the geometrical or trigonometric leveling [Baran et al., 1997; Baran, 2012; Baran Marushchak, 2015].

It goes from this formula that in the normal conditions of building and exploitation of construction the settling has sign "minus", which is automatically taken into account in algorithms and programs of the computer processing of data and computer graphics. However, in practice this sign often is missing, so as the word "settling" is understood as lowering of height point of earthly surface that displayed on profiles and charts of settling of control benchmarks.

The approximated settling $S_{t_{i}}^{a}$ on slowly coercible soils in theory is described by the exponent (1) and together with the measured settling forms equalization of amendments

$$
S_{t_{i}}^{a}-S_{t_{i}}=v_{i}
$$

where $v_{i}-$ an amendment is in the measured settling

Approximation of settling by the exponent requires a reduction of equalization of amendments (10) to the linear form (linearization), as a theoretical value of settling $S_{t_{i}}^{a}$ is described by a nonlinear function (1). For linearization of such functions there is used its expansion in the Taylor series, limited by the first members of expansion, i.e. erecting the theoretical value of settling to such kind:

$$
\begin{aligned}
& S_{t_{i}}^{a}=S_{t_{i}}^{0}+\left(\frac{d S_{t_{i}}}{d S_{k}}\right)^{0} \Delta S_{k}+\left(\frac{d S_{t_{i}}}{d k}\right)^{0} \Delta k ; \\
& S_{t_{i}}^{0}=S_{k}^{0}\left(1-e^{-k_{0} t_{i}}\right) ;\left(\frac{d S_{t_{i}}}{d S_{k}}\right)^{0}=1-e^{-k_{0} t_{i}}=a_{i} ; \\
& \left(\frac{d S_{t_{i}}}{d k}\right)^{0}=S_{k_{0}} t_{i} e^{-k_{0} t_{i}}=S_{k_{0}} t_{i}\left(1-a_{i}\right)=b_{i} ; \\
& \Delta S_{k}=S_{k}-S_{k_{0}} ; \quad \Delta k=k-k_{0} .
\end{aligned}
$$

The calculation of these elements of equalizations of amendments is conducted by the approximate values of the eventual settling $S_{k}^{0}$ and $\mathrm{k}_{0}$. But if $S_{k}^{0}$ is determined more precisely by two last values of the measured settling, especially in the stage of their fading, then for determination $k_{0}$ we use exact formula [Baran, 2012]

$$
k_{0}=-\frac{1}{\bar{t}} \ln \left(1-\frac{\bar{S}}{S_{k}^{0}}\right)
$$

where $\bar{t}=[t] / n$ i $\bar{S}=[S] / n-$ mean values of time interval and settling, which assist diminishing of amount of iterations defining of task.

Then equalizations of amendments (10) considering (11) for the n measurements will be:

$$
a_{i} \cdot \Delta S_{k}+b_{i} \cdot \Delta k_{i}+l_{i}=v_{i} ; \quad l_{i}=S_{t_{i}}^{0}-S_{t_{i}},
$$

where $l_{i}-$ free member of equalization, $i=1,2,3, \ldots, n-$ number of observations.

Laying down and defining two normal equalizations

$$
\begin{aligned}
& {[a a] \Delta S_{k}+[a b] \Delta k+[a l]=0 ;} \\
& {[a b] \Delta S_{k}+[b b] \Delta k+[b l]=0,}
\end{aligned}
$$

we will get desired unknown values

$$
S_{k}=S_{k}^{0}+\Delta S_{k} ; \quad k=k^{0}+\Delta k,
$$

using which according to the formula (1) of exponent it is possible to calculate the final values of approximated settling $S_{t_{i}}^{a}$, and then the values of amendments $v_{i}$, the sum of which in theory under the condition of LSM (least squares method) must be equal a zero, i.e.:

$$
[v] \approx\left[S^{a}\right]-[S] \approx 0,
$$

that serves as control of rightness of solution of the task.

The results of calculations of the approximated settlings $S_{t_{i}}^{a}$ are drawn on a chart as points, connected by a smooth line and then the control of the rightness of reflection of line of approximation in relation to the polyline of the measured settling is implemented. They must coincide within the limits of maximal rejection $\Delta v \leq 3 \mu$.

The errors of determination of parameters of approximation are calculated by the formulas

$$
\begin{gathered}
\mu=\sqrt{\frac{\left[v^{2}\right]}{n-2}} ; m_{S_{k}}=\mu \sqrt{Q_{11}} ; \\
m_{k}=\mu \sqrt{Q_{22}} ; \quad Q_{11}=\frac{[b b]}{D} ; \\
Q_{22}=\frac{[a a]}{D} ; \quad D=[a a] \cdot[b b]-[a b]^{2} .
\end{gathered}
$$

If there is a requirement of estimation of accuracy of the approximated settling in any cycle of observation, then error is

$$
\begin{gathered}
m_{S_{t_{i}}^{a}}=\mu / \sqrt{P_{S_{t_{i}}^{a}}} ; \\
P_{S_{t_{i}}^{a}}=a_{i}^{2} Q_{11}+b_{i}^{2} Q_{22}+2 a_{i} b_{i} Q_{12} ;
\end{gathered}
$$




$$
Q_{12}=-\frac{[a b]}{[a a]} Q_{22}
$$

where $a_{i}, b_{i}$-coefficients of equalizations of amendments in the cycle.
Table 2 shows an example of determination of parameters of approximation of settling by the exponent for one control benchmark of building which are obtained from leveling of II class in 9 working cycles during 4 years ( 0 -th cycle is initial). See Fig. 2 for chart of settling.

Determination of parameters of approximation of settling by the exponent

\begin{tabular}{|c|c|c|c|c|c|c|c|c|c|c|c|}
\hline $\begin{array}{c}\text { No of cycles } \\
\text { of observ. }\end{array}$ & 0 & 1 & 2 & 3 & 4 & 5 & 6 & 7 & 8 & total & $\begin{array}{c}\text { averag } \\
\mathrm{e}\end{array}$ \\
\hline$t$, monthc & 0 & 6 & 12 & 18 & 24 & 30 & 36 & 42 & 48 & 216 & 27 \\
\hline$S_{t}, \mathrm{~mm}$ & 0 & 19.4 & 42.0 & 54.5 & 65.7 & 68.1 & 74.0 & 76.0 & 76.2 & 479.5 & 59.5 \\
\hline
\end{tabular}

1. Calculation of approximate values $\left(S_{k}^{0} \approx 76 \mathrm{~mm} ; \mathrm{k} \approx 0,056 \mathrm{~mm} / \mathrm{month}\right)$

\begin{tabular}{|c|c|c|c|c|c|c|c|c|c|c|c|}
\hline$S_{t}^{0}, \mathrm{~mm}$ & 0 & 21.7 & 37.2 & 48.3 & 56.2 & 61.8 & 65.9 & 68.8 & 71.8 & 430.7 & 53.8 \\
\hline$l, \mathrm{~mm}$ & 0 & 2.3 & -4.8 & -6.2 & -9.5 & -6.3 & $-8,1$ & -7.2 & -5.4 & -45.2 & -5.6 \\
\hline $\boldsymbol{a}$ & 0 & 0.285 & 0.489 & 0.635 & 0.739 & 0.814 & 0.861 & 0.867 & 0,905 & - & - \\
\hline $\boldsymbol{b}$ & 0 & 326 & 466 & 499 & 476 & 425 & 364 & 304 & 248 & - & - \\
\hline
\end{tabular}

2. Exact calculation of the parameters of the settlings $\left(S_{k}^{0} \approx 83,5 \mathrm{~mm} ; \bar{k}^{0} \approx 0,058 \mathrm{~mm} / \mathrm{month}\right)$

\begin{tabular}{|c|c|c|c|c|c|c|c|c|c|c|c|}
\hline$S_{t_{i}}^{a}, \mathrm{~mm}$ & 0 & 24.5 & 41.6 & 53.7 & 62.2 & 68.1 & 72.3 & 75.2 & 78.3 & 474.9 & 59.4 \\
\hline$v, \mathrm{~mm}$ & 0 & 5.1 & -0.4 & -0.8 & -3.5 & 0.0 & -1.7 & -0.8 & 1.1 & -1.0 & -0.1 \\
\hline
\end{tabular}

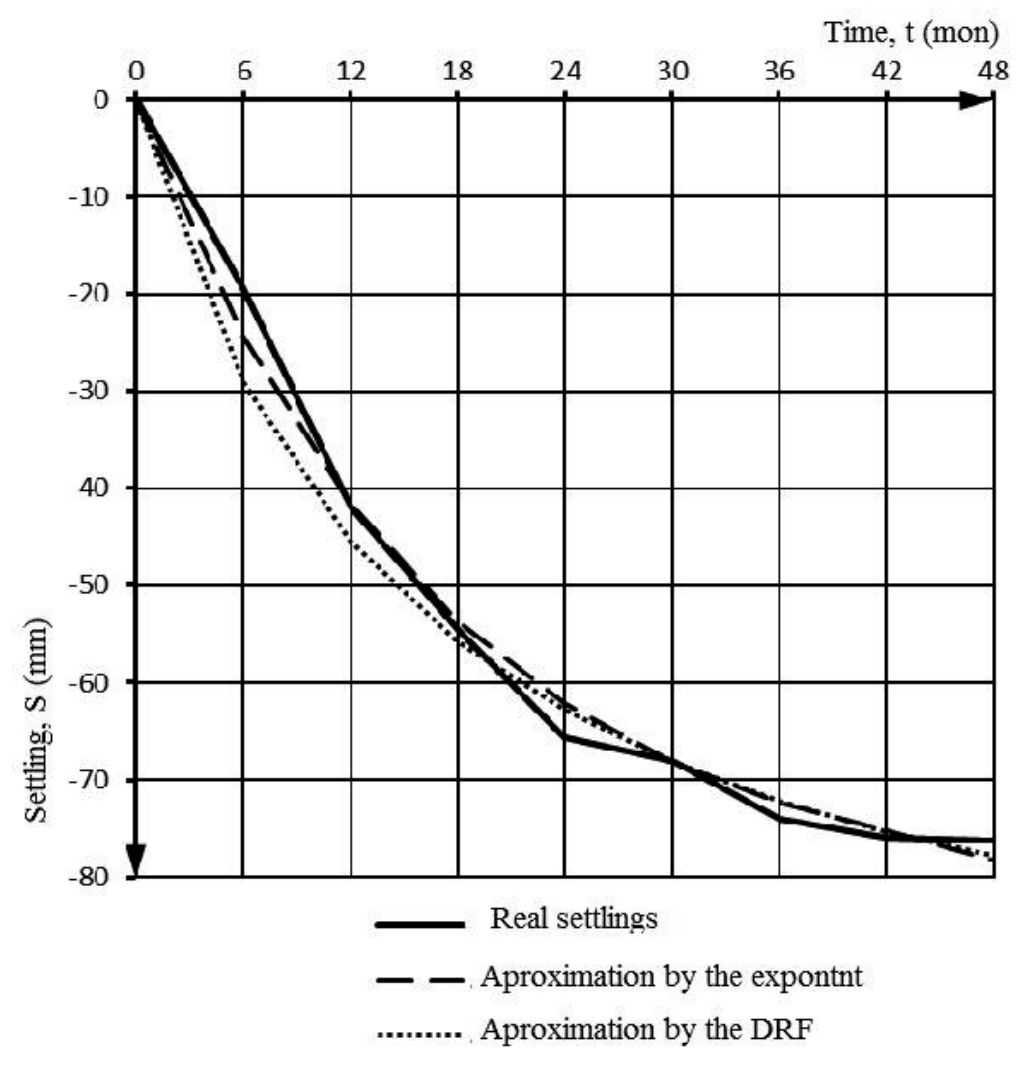

Fig. 1. Chart of approximation of real settlings by the exponent and FRF 
It is expedient from the beginning to build the chart of the measured settlings of benchmark (Fig. 1), to monitor the tendency of their fading and to define the approximate value of the eventual settling, for example, when $S_{k}^{0} \approx S_{7}=76$ i $\mathrm{mm}$ $\bar{S}=475.9 / 8=59.5 \mathrm{~mm}$ and $\bar{t}=216 / 8=27$ months according to the formula (12) the mean value of coefficient is $\bar{k}^{0}=0.056 \mathrm{~mm} / \mathrm{month}$, what allows to be limited to the one (rarely two) iterations, although it can depend on the amount of measurements and changes of parameters of settling process. But despite on these advantages, especially implementation of the simplified calculations, the method of the "mean-coefficient" requires a development and decision of normal equalizations, as without this it is impossible to estimate accuracy of determination of parameters of approximation by formulas (17)-(18). In this case the amendment $\Delta S_{k}$ is determined that provides the amendment of approximate value of the eventual settling $S_{k}^{0}$, using which according to the formula (12) the mean-coefficient of intensity of settling was determined. Amendments to the eventual settling and approximate absolute value of the coefficient are entered with their signs. If the settling on the chart are assigned a "minus" sign, which represents the real direction of vector of lowering of position of benchmark, then it also will require the change of sign for amendment $\Delta S_{k}$.

According to Table 2 the normal equations are created

$$
\begin{aligned}
& 4.3711 \Delta S_{k}+2157.4 \Delta k-36.346=0 \\
& 2157.4 \Delta S_{k}+1267037 \Delta k-18258=0,
\end{aligned}
$$

from where when $\mathrm{D}=883818 ; \mathrm{D}_{\mathrm{S}}=6660422$ and $\mathrm{D}_{\mathrm{k}}=1395.1$ there were obtained amendments and then the unknown values. Therefore, the approximated settlings $S_{t_{i}}^{a}=83.5\left(1-e^{-0,058 t_{i}}\right)$.

Now, according to the formula (10), the amendments to the measured settlings are calculated, the sum of which is $-0.1 \mathrm{~mm}$, and, therefore, it allows us to conclude that the problem is solved correctly and there is no need for calculations in the 2nd approximation. This is evidenced by the results of the evaluation of the accuracy of the approximation parameters determined by the formulas (17) and (18), namely:

$$
\begin{gathered}
\mu=\sqrt{40.86 / 6}=2.6 \mathrm{~mm} ; \mathrm{m}_{\mathrm{S}_{\mathrm{k}}}=2.6 \sqrt{1.43}=3.1 \mathrm{~mm} ; \\
\mathrm{m}_{\mathrm{k}}=2.6 \sqrt{0.0000049}=0.006 \mathrm{~mm} / \mathrm{mon} .
\end{gathered}
$$

For the example we present the definition of the error of the approximated settling of the controlbenchmark in the 4th cycle, where, according to the formula (18), when

$$
\begin{gathered}
\mu=2.6 \mathrm{~mm} ; \quad a_{4}=0.739 ; \quad b_{4}=476 \\
\text { i } Q_{12}=\frac{-2157}{4,3711}(0,0000049)=0,0024 \text { error } \\
m_{S_{4}}=2,6 \sqrt{\begin{array}{l}
0.739^{2} \cdot 1.43+476^{2} \cdot 0.0000049+ \\
+2 \cdot 0.739 \cdot 476(-0.0024)
\end{array}}=1.2 \mathrm{~mm},
\end{gathered}
$$

which agrees with the level of accuracy of leveling and the data of the approximation chart of measured settlings.

Approximated settlings in Fig. 1 reflect the character of the deformation process in the zone of the location of this benchmark. Thus, the method of "mean coefficient of intensity of settlings" greatly simplifies the complicated system of iterative calculations and provides a high efficiency analysis of data of the monitoring of deformation processes of structures.

Note that if observation is carried out by control marks located on tiers of high-rise buildings, then corrections for the temperature deformation of the structure must be repeatedly introduced into their height marks [Baran, 2007].

For efficient organization of cyclic observations it is expedient to determine rational inter-cycle intervals whose components are calculated on the basis of formulas (2) and (3). There is also an example of determination of these intervals.

Approximation of settlings by a finelyrational function. Settling is described by a simple dependence [Ziborov, 2004]

$$
S_{t_{i}}=\frac{a t_{i}}{b+t_{i}},
$$

where $a, b-$ unknown parameters of approximation which are to be determined using equations of amendments

$$
t_{i} a-S_{t_{i}} b-t_{i} S_{t_{i}}=v_{i} \quad(i=1,2,3, \ldots, n) .
$$

The problem is solved by LSM with two square equations

$$
\begin{aligned}
{\left[t^{2}\right] a-[t S] b-\left[t^{2} S\right] } & =0 \\
-[t S] a+\left[S^{2}\right] b+\left[t S^{2}\right] & =0 .
\end{aligned}
$$


For example of the problem solution it is taken the same measurement data of settlings in 9 cycles from the Table 2, using which the following normal equations are obtained:

$$
\begin{aligned}
7344 a-14734.8 b & =529070.4 ; \\
-14734.8 a+31123.15 b & =-1038051.84
\end{aligned}
$$

and the approximation parameters were determined: the determinant $\mathrm{D}=11454082.56$; $\mathrm{D}_{\mathrm{a}}=1170851168 ; \quad \mathrm{D}_{\mathrm{b}}=172293817 ;$ the coefficients $\mathrm{a}=102.2213 \mathrm{~mm} /$ month. and $\mathrm{b}=$ $=15.042$ months. Approximated values of settling are calculated by a simple formula (19). The results of calculations are shown in the Table 3.

Table 3

Approximation of settlings by a finely-rational function

\begin{tabular}{|c|c|c|c|c|c|c|c|c|c|c|}
\hline Cycle & 0 & 1 & 2 & 3 & 4 & 5 & 6 & 7 & 8 & Sum \\
\hline $\mathrm{t}$, month & 0 & 6 & 12 & 18 & 24 & 30 & 36 & 42 & 48 & 216 \\
\hline $\mathrm{S}_{\mathrm{t}}, \mathrm{mm}$ & 0 & 19.4 & 42.0 & 54.5 & 65.7 & 68.1 & 74.0 & 76.0 & 76.2 & 475.9 \\
\hline $\mathrm{S}_{\mathrm{t}}^{\mathrm{a}}, \mathrm{mm}$ & 0 & 29.2 & 45.4 & 55.7 & 62.8 & 68.1 & 72.1 & 75.3 & 77.8 & 486.4 \\
\hline $\mathrm{v}=\mathrm{S}_{\mathrm{t}}^{\mathrm{a}}-\mathrm{S}_{\mathrm{t}}, \mathrm{mm}$ & 0 & 9.8 & 3.4 & 1.2 & -2.9 & 0.0 & -1.9 & -0.7 & 1.6 & 10.5 \\
\hline
\end{tabular}

As we see, the sum of all amendments (without taking into account the amendment of the 1-st cycle) is close to zero, the sum of their squares is $124.11 \mathrm{~mm}^{2}$ and the error of settling $\mu=\sqrt{124.11 / 6}=4.5 \mathrm{~mm}$.

Errors of coefficients $\boldsymbol{a}$ and $\boldsymbol{b}$ respectively are:

$$
\begin{aligned}
& m_{a}=4,5 \sqrt{0.0027}=0.23 \mathrm{~mm} ; \\
& m_{a}=4.5 \sqrt{0.00064}=0.11 \mathrm{mon} .
\end{aligned}
$$

Similarly, to the previous method, according to the approximation data, the chart of settlings with an approximation curve is formed and the correctness of the reflection of the settling process is evaluated (see Fig. 1). By comparing the positions of the curves of approximation of settlings obtained by the two described methods, we can state that the exponent asymptotically better reflects the approximation of settlings to stabilization than the method of finely-rational function.

However, the method of finely-rational function is easier to implement than the exponential and ensures a high accuracy of approximation. To calculate the allowable time interval between observations cycles it is necessary to consider settling speed. So we obtained the following dependencies:

$$
\begin{gathered}
v=\frac{\Delta S_{i, i+1}}{\Delta t_{i, i+1}} \approx \frac{a b}{\left(b+\bar{t}_{i, i+1}\right)^{2}} ; \\
\Delta t_{i, i+1} \approx \frac{\Delta S}{a b}\left(b+\bar{t}_{i, i+1}\right)^{2} ; m_{\Delta t_{i, i+1}}=\Delta t_{i, i+1} / 10 \sqrt{2},(22)
\end{gathered}
$$

where $\bar{t}_{i, i+1}=\left(t_{i}+t_{i+1}\right) / 2-$ average time interval between adjacent cycles.

According to Table 3, the error of keeping the time interval between the execution of the 2 nd and 3 rd cycles is

$$
m_{\Delta t_{i, i+1}} \approx \frac{12.5 \cdot(15+15)^{2}}{1500 \cdot 10 \sqrt{2}} \approx 0.54 \text { mon. } \approx 16 \text { days. }
$$

If the parameters of approximation are unknownin the initial period of observations, then their approximate values can be taken respectively as magnitudes $a \geq S_{k}$ and $b \leq t_{k}$. Obviously, in the stage of settlings stabilization, when $b \approx t_{k}$, settling speed $v \approx S_{k} / 4 t_{k}$, and $\Delta t_{k} \approx 4 t_{k} m_{\Delta S} / S_{k}$. Therefore, when $S_{k} \approx 76 \mathrm{~mm}, t_{k}=48 \mathrm{mon}$. with a minimum error of settling measurements $m_{\Delta S}=1 \mathrm{~mm}$ the error of the time interval between the measurement cycles should not exceed 2.5 months.

\section{Approximation of settlings by a polynomial} function. The general function of the approximation of settlings is described by the expression

$$
S_{t}=a_{1} t+a_{2} t^{2}+a_{3} t^{3}+\ldots+a_{m} t^{m},
$$

where $a_{i}-$ coefficients of a polynomial $(i=1,2,3, \ldots, m)$. 
In practice, polynomials of the 2nd and 3rd order, in other words square and cubic parabolas are predominantly used.
See Table 1 for an example of the solution of the approximation problem with the data of previous settlings shown.

Table 4

Approximation of settlings by a cubic parabola

\begin{tabular}{|l|c|c|c|c|c|c|c|c|c|c|}
\hline $\begin{array}{c}\text { No. of } \\
\text { observations } \\
\text { cycles }\end{array}$ & 0 & 1 & 2 & 3 & 4 & 5 & 6 & 7 & 8 & Sum \\
\hline$t$, mon. & 0 & 6 & 12 & 18 & 24 & 30 & 36 & 42 & 48 & 216 \\
\hline$S_{t}, \mathrm{~mm}$ & 0 & 19.4 & 42.0 & 54.5 & 65.7 & 68.1 & 74.0 & 76.0 & 76.2 & 475.9 \\
\hline$S_{t}^{a}, \mathrm{~mm}$ & 0 & 21.2 & 39.0 & 53.5 & 64.6 & 72.4 & 76.8 & 77.9 & 75.6 & 481.0 \\
\hline$v=S_{t}^{a}-S_{t}, \mathrm{~mm}$ & 0 & 1.8 & -3.0 & -1.0 & -1.1 & 4.3 & 2.8 & 1.9 & -0.6 & 5.1 \\
\hline
\end{tabular}

According to (23), for a square parabola, the equation of amendments and then the normal equations are compiled in form

$$
\begin{gathered}
t_{i} a_{1}+t_{i}^{2} a_{2}-S_{i}=v_{i} ;(i=1,2,3, \ldots, m), \\
{\left[t^{2}\right] a_{1}+\left[t^{3}\right] a_{2}-[t S]=0 ;} \\
{\left[t^{3}\right] a_{1}+\left[t^{4}\right] a_{2}-\left[t^{2} S\right]=0,}
\end{gathered}
$$

and finally, the real equation:

$$
\begin{aligned}
7344 a_{1}+279936 a_{2}+14734.8 & =0 ; \\
279936 a_{1}+11368512 a_{2}-529070.4 & =0 .
\end{aligned}
$$

Solving this system of equations it is obtained: $a_{1}=3.8144 ; a_{2}=-0.046677 ; D=5126188032$;

$$
Q_{11}=0.00222 ; Q_{22}=0.0000014 \text {. }
$$

Now approximated settlings can be calculated by the formula

$$
S_{i}^{a}=3.8144 t_{i}-0.046677 t_{i}^{2},
$$

with results are shown in Table 4.

In the lower part of the table there are shown amendments the sum of which is almost close to zero. It allows determine the error of one settling $\mu=\sqrt{44.75 / 6}=2.73 \mathrm{~mm}$. Errors of determination of the approximation coefficients are:

$$
\begin{gathered}
m_{a_{1}}=2,73 \sqrt{0,0022}=0,13 \mathrm{~mm} / \mathrm{mon} ; \\
m_{a_{2}}=2.73 \sqrt{0.0000014}=0.0033 \mathrm{~mm} / \mathrm{mon}^{2} .
\end{gathered}
$$

If we form the chart of real and approximated settlings, one can see that the square parabola in the last cycle in some way reduces the settlings (in this example, by $3 \mathrm{~mm}$ ). That is close to the error of determining the settlings themselves. Therefore, in order to avoid such misunderstandings, it is more expedient to apply a cubic parabola whose parameters can be determined from the system of three normal equations

$$
\begin{gathered}
{[t] a_{1}+\left[t^{2}\right] a_{2}+\left[t^{3}\right] a_{3}-[t S]=0} \\
{\left[t^{2}\right] a_{1}+\left[t^{3}\right] a_{2}+\left[t^{4}\right] a_{3}-\left[t S^{2}\right]=0} \\
{\left[t^{3}\right] a_{1}+\left[t^{4}\right] a_{2}+\left[t^{5}\right] a_{3}-\left[t S^{3}\right]=0 .}
\end{gathered}
$$

Approximate settling are calculated by the formula (23). The estimation of the accuracy of the parameters is carried out using the error of settling the coefficients of the matrix of normal equations.

\section{Approximation of periodic settlings by a} sinusoid. The sinusoid can be used in combination with a straight line or a parabola, or independently for settlings that have oscillatory character, caused by periodic changes in ground water level (flooding) or seasonal changes in the temperature of a building. It should be noted that in the literature, in particular in [Baran et al., Handbook of Engineering Geodesy], it is often recommended the function of straight line or polynomial have coefficients at $\boldsymbol{t}$. This violates the basic condition of approximation, so that its curve passes through the beginning of the coordinates, where they are zero. Below a simple way of approximating a periodic function with straight line is presented as following:

$S^{a}=b_{1} t+b_{2} \cos \omega t+b_{3} \sin \omega t ; \quad \omega=2 \pi / T$,

$S^{a}=b_{1} t+b_{2} \cos \omega t+b_{3} \sin \omega t ; \quad \omega=2 \pi / T$, (27)

where $\omega-$ frequency of oscillations, $T=[t]-$ period of oscillations.

Based on the amendment equation

$$
t_{i} b_{1}+\cos \omega t_{i} b_{2}+\sin \omega t b_{3}-S_{t_{i}}=v_{i}
$$

the system of normal equations is formed and solved 


$$
\begin{array}{rll}
{\left[t^{2}\right] b_{1}+[t \cos \omega t] b_{2}} & +[t \sin \omega t] b_{3} & =[t S] ; \\
{[t \cos \omega t] b_{1}+\left[\cos ^{2} \omega t\right] b_{2}} & +[\cos \omega t \sin \omega t] b_{3} & =[S \cos \omega t] ; \\
{[t \sin \omega t] b_{1}+[\cos \omega t \sin \omega t] b_{2}+\left[\sin ^{2} \omega t\right] b_{3}} & =[S \sin \omega t] .
\end{array}
$$

An example of settling measurement in 9 working cycles is given in Table 5.

\section{Approximation of settlings by a straight line and a sinusoid}

Table 5

$(\mathrm{T}=478 ; 0.013145 \mathrm{rad} ;[\mathrm{S}]=210 \mathrm{~mm})$

\begin{tabular}{|c|c|c|c|c|c|c|c|c|c|c|c|c|c|}
\hline $\begin{array}{c}\text { Number } \\
\text { of cycles }\end{array}$ & 0 & 1 & 2 & 3 & 4 & 5 & 6 & & 7 & 8 & 9 & Sum & Medium \\
\hline$t$, mon. & 0 & 12 & 22 & 33 & 44 & 52 & 64 & & 73 & 82 & 96 & 478 & 53.1 \\
\hline$S$, мм & 0 & 24 & 30 & 15 & 21 & 27 & 18 & & 26 & 24 & 25 & 210 & 23.3 \\
\hline$\omega t$, рад. & 0 & 0.158 & 0.289 & 0.434 & 0.578 & 0.684 & 0.841 & & 0.960 & 1.078 & 1.262 & - & - \\
\hline $\cos \omega t$ & 0 & 0.988 & 0.960 & 0.907 & 0.837 & 0.775 & 0.666 & & 0.574 & 0.473 & 0.304 & - & - \\
\hline sin $\omega t$ & 0 & 0.157 & 0.285 & 0.420 & 0.547 & 0.632 & 0.745 & & 0.820 & 0.880 & 0.953 & - & - \\
\hline$S^{a}, \mathrm{~mm}$ & 0 & 24.5 & 23.9 & 23.1 & 22.4 & 22.0 & 22.0 & & 22.4 & 23.4 & 26.2 & 209.9 & 23.3 \\
\hline $\mathrm{v}, \mathrm{mm}$ & 0 & 0.5 & -6.1 & 8.1 & 1.4 & -5.0 & 4.0 & & -3.6 & -0.6 & 1.2 & -0.1 & -0.01 \\
\hline
\end{tabular}

According to the Table 5 the normal equations are composed

$$
\begin{aligned}
31722 b_{1}+292.582 b_{2}+350.109 b_{3} & =11189 ; \\
292.582 b_{1}+5.10962 b_{2}+3.43059 b_{3} & =150.462 ; \\
350.109 b_{1}+3.43059 b_{2}+3.89038 b_{3} & =126.832
\end{aligned}
$$

from where we received:

$$
b_{1}=0.830492 \mathrm{~mm} / \text { month; }
$$

$$
b_{2}=24.9615 ; b_{3}=-64.1489 \text {. }
$$

Then by equations (27) and (28) approximated settlings and amendments, are calculated and are given in the lower part of the Table 5. The sum of these settlings is $209.9 \mathrm{~mm}$, and amendments $-0.1 \mathrm{~mm}$, which indicate the correctness of the solution of the problem. The sum of the squares of the amendments equals $160.79 \mathrm{~mm}^{2}$ and the mean square error of the approximated settling is $5.2 \mathrm{~mm}$.

Time, $\mathbf{t}(\mathbf{m o n})$

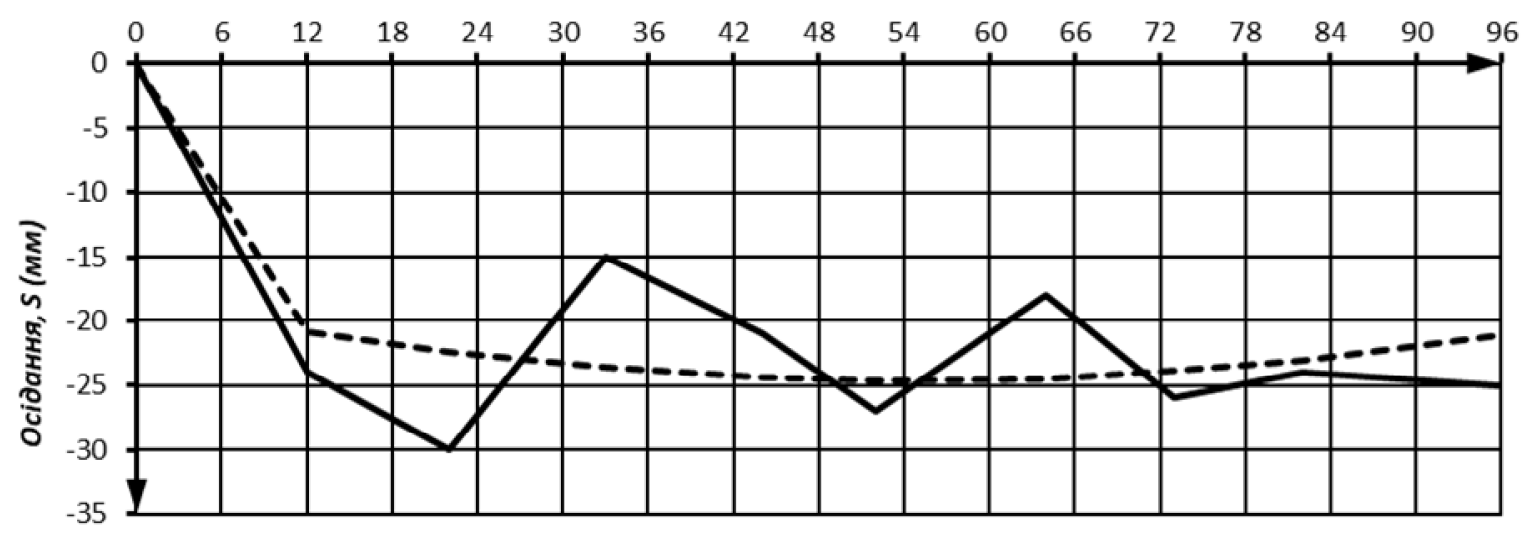

Fig. 2. Scheme of approximation of real settling by sinusoid:

\section{- - - rea sedimen; - - approximation of settling by sinusoid}

The chart of settlings (Fig. 2) shows the periodic nature of real settlings, but the curve of approximated settlings does not reflect their oscillatory nature, which may be the subject of special research. Moreover, joining the line to the sinusoid has little effect on the approximation 
process, which makes it easy to see when to use only the sinusoid, taking equalization of the amendments (27) without the first term, that is, in the form:

$$
\cos \omega t_{i} b_{2}+\sin \omega t b_{3}-S_{t_{i}}=v_{i}
$$

In this case, the normal equations (29) will be:

$5.10962 b_{2}+3.43059 b_{3}=150.462$;

$$
3.43059 b_{2}+3.89038 b_{3}=126.832 \text {, }
$$

from where we received: $b_{2}=18.553$ i $b_{3}=16.232 \mathrm{~mm}$.

To simplify the calculations by formulas (27) and (30), it is expedient to replace their sinusoidal part with the expression

$$
\begin{gathered}
b_{2} \cos \omega t+b_{3} \sin \omega t=A \sin (\omega t+\varphi) ; \\
A=\sqrt{b_{2}^{2}+b_{3}^{2}} ; \varphi=\operatorname{arctg}\left(b_{2} / b_{3}\right),
\end{gathered}
$$

where $A, \varphi-$ amplitude and shift of phase of oscillations.

The described transformation is caused by the fact that the coefficients $b_{2}=A \sin \varphi$ and $b_{2}=A \cos \varphi$ together with the angle $\omega t$ form the expression of sine of sum of two angles.

The settlings and amendments to them approximated by the sinusoid are calculated by formulas (27) taking into account (30) and are shown in Table 6 . For this we used $A=24.6 \mathrm{~mm}$ and $\mathrm{i} \varphi=\operatorname{arctg}(1.1430)=0.8520 \mathrm{rad}$.

Table 6

Approximation of settlings by a sinusoid

\begin{tabular}{|c|c|c|c|c|c|c|c|c|c|c|c|c|}
\hline $\begin{array}{c}\text { Cycle } \\
\text { No }\end{array}$ & 0 & 1 & 2 & 3 & 4 & 5 & 6 & 7 & 8 & 9 & Sum & Medium \\
\hline$T, \mathrm{mon}$. & 0 & 12 & 22 & 33 & 44 & 52 & 64 & 73 & 82 & 96 & 478 & 53.1 \\
$S, \mathrm{~mm}$ & 0 & 24 & 30 & 15 & 21 & 27 & 18 & 26 & 24 & 25 & 210 & 23.3 \\
\hline$S^{a}, \mathrm{~mm}$ & 0 & 20.9 & 22.4 & 23.6 & 24.4 & 24.6 & 24.5 & 23.9 & 23.1 & 21.1 & 208.5 & 23.3 \\
$v, \mathrm{~mm}$ & 0 & -3.2 & -7.6 & 8.6 & 3.4 & -2.4 & 6.4 & -2.1 & -1.0 & -3.9 & -1.8 & -0.2 \\
\hline
\end{tabular}

The sum of approximated settlings is $208.5 \mathrm{~mm}$, the sum of amendments is $-1.8 \mathrm{~mm}$, the sum of their squares is $220.86 \mathrm{~mm}^{2}$, and the mean square error of the approximated settling is $5.6 \mathrm{~mm}$ (for sinusoid with the straight line it is equal $5.2 \mathrm{~mm}$, and the magnitude of the mean square deviations between the two approximating sinusoids is $2.6 \mathrm{~mm}$ ). It indicates the possibility of application of a simple sinusoid for the conditional approximation of cyclic settlings. The more complex functions of polynomials for such tasks are considered in the work [Bryś, Przewlocki, 1998].

\section{Scientific novelty and practical significance}

The performed improvements increase the efficiency and representativeness of the data of approximation and help to reduce the volume of computations. The development of the method for calculating time intervals between observation cycles for various approximation functions allows us to exclude practically the iteration process of determination of the coefficient of intensity of the settling for the exponent and application of this coefficient to specify the coefficients of compressibility or porosity of the soil that are determined by its laboratory research.

\section{Conclusions}

Summing up the consideration of settlings approximation methods we can make the following recommendations.

1. For a more complete analysis of the deformation field of constructions, the approximation method by the exponent is most suitable. It allows determining the integral coefficient of the intensity of settling, and, in accordance with the formulas (2) specifying the values of the coefficients of compressibility or porosity of the soil.

2. The method of finely-rational functions is the simplest in implementation of a computational process. According to all indicators it significantly predominates even simple polynomials method.

3. Methods of simple polynomials and sinusoids are not suitable for approximation of periodic functions, therefore it is necessary to perform special studies for their complicated expressions.

4. The accuracy of determination of rational inter cyclical time intervals depends on the speed of the settling process and the form of the approximation curve. 


\section{REFERENCES}

Baran P. I., Viduev N. G., Vojtenko S. P. et al. Spravochnik po inzhenernoj geodezii [Handbook of Engineering Geodesy] pod. obshhej red. N. G. Vidueva. Kyiv: Vishha shk., 1978, 376 p.

Baran, P. I., Soloviov F. F., Chornokin V. Ya. Tryhonometrychne niveliuvannia $v$ inzhenernoheodezychnykh robotakh [Trigonometric leveling in engineering and geodetic works]. za red. prof. P. I. Barana. Kyiv: Ukrheodezkartohrafiia. 1997, $130 \mathrm{p}$.

Baran, P. I. Inzhenerna heodeziia: Monohrafiia [Engineering Geodesy: Monograph ]. Kyiv: PAT "VIPOL", 2012, 618 p.

Baran, P. I., Marushchak M. P. Topohrafiia ta inzhenerna heodeziia: pidruch. dlia stud. heodez. neheodez. spets. VNZ [Topography and engineering geodesy]. Kyiv: Znannia Ukrainy, 2015, 463 p.

Baran,P. I. Vrakhuvannia temperaturnoi deformatsii pry vymiriuvanni horyzontalnykh $i$ vertykalnykh zmishchen inzhenernykh sporud [Considering thermal strain when measuring horizontal and vertical displacements of engineering structures]. Visn. Heodez. ta kartohr. 2007, no. 4, pp. 14-20.
Bryś H., Przewlocki S. Geodezyjne metody pomiaróv przemieszszeń budowli [Geodetic methods of measurement of building displacements] $W N P W N$, Warszawa, 1998, $243 \mathrm{p}$.

Viduev, N. G., Staroverov V. S. Raschet neobhodimoj tochnosti nabljudenij za osadkami inzhenernyh sooruzhenij [The calculation of the necessary accuracy of observations over the settlingation of engineering structures]. Sb. Inzh. geodez., 1972, issue 12 , pp. 3-12.

DSTU B V.2.1-30:2014 Grunty. Metody vymiriuvannia deformatsii osnov budynkiv $i$ sporud [Methods of measuring the deformations of the bases of buildings and structures]

Ziborov, V. V. Novaja metodika opredelenija kojefficientov modeli osadochnogo processa [ A new technique for determining the coefficients of the settling process model]. Sb. Inzh. geodez., 1972, issue 39 , pp. 72-75.

Ziborov, V. V. O modelirovanii osadochnogo processa drobno-racional'noj funkciej [On the modeling of the settlingary process by a fractional-rational function]. Zb. Inzh. geodez., 2004, issue 50, pp. $72-75$.

\section{П. БАРАН}

Івано-Франківський національний технічний університет нафти і газу, вул. Карпатська, 15, Івано-Франківськ, Україна, 76019

\section{ЕФЕКТИВНІ МЕТОДИ АПРОКСИМАЦІЇ ТА ПРОГНОЗУВАННЯ ОСІДАНЬ ІНЖЕНЕРНИХ СПОРУД}

Мета досліджень. Удосконалення методів апроксимації осідань експоненціальною, дрібнораціональною, поліномінальною та синусоїдними функціями з визначенням інтервалів між циклами спостережень. Методика і результати роботи. Розглянуто методи апроксимації та прогнозування осідань контрольних реперів і марок споруд. Особливу увагу звернено на експоненціальну функцію з використанням простого і точного способу визначення коефіцієнта інтенсивності осідання за середніми значеннями самих осідань і часових інтервалів, який дає змогу суттєво зменшити обсяг ітераційних обчислень. Запропонований у статті точний (інтегральний) метод визначення коефіцієнта інтенсивності осідання практично дає можливість вилучити ітераційний процес обчислень і за даними апроксимації осідань уточнювати коефіцієнти стискування або пористості грунту, які визначаються із лабораторних досліджень грунту. Для заміни методів поліному i синусоїди розроблено алгоритм апроксимації осідань методом дрібнораціональної функції, що його запропонував В. В. Зіборов [Зиборов, 1972], та методику визначення міжциклових часових інтервалів для виконання раціональних моніторингових спостережень за вертикальними зміщеннями споруд. Показано ефективність застосування методу дрібнораціональної функції та практичну недоцільність використання функції поліному та синусоїди для апроксимації осідань. Доведено, що запропонований В. В. Зіборовим метод дрібнораціональної функції є найпростішиим в організації обчислень. Наукова новизна. Виконані удосконалення підвищують ефективність і репрезентативність даних апроксимації, сприяють зменшенню обсягу обчислень. Практична цінність. Розроблення методики розрахунку часових інтервалів між циклами спостережень для різних функцій апроксимації практично дає змогу вилучити ітераційний процес визначення коефіцієнта інтенсивності осідання для експоненти та використання цього коефіцієнта для уточнення коефіцієнтів стисливості або пористості грунту, які визначаються за його лабораторними дослідженнями.

Ключові слова: моніторинг, осідання, апроксимація, експонента, дрібно-раціональна функція, поліном, синусоїда, міжцикловий інтервал спостережень.

Received 23.01.2018 